\title{
Variation among Australian accessions of the wild mungbean (Vigna radiata ssp. sublobata) for traits of agronomic, adaptive, or taxonomic interest
}

\author{
R. J. Lawn ${ }^{\mathrm{A}, \mathrm{C}}$ and G. J. Rebetzke

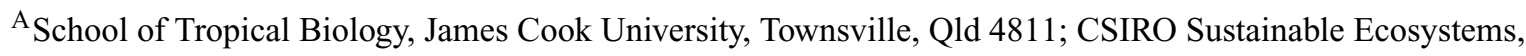 \\ Davies Laboratory, Townsville, Qld 4814, Australia. \\ ${ }^{B}$ Department of Agriculture, University of Queensland, St Lucia, Qld 4072; \\ present address: CSIRO Plant Industry, PO Box 1600, Canberra, ACT 2601, Australia. \\ ${ }^{\mathrm{C}}$ Corresponding author. Email: robert.lawn@jcu.edu.au
}

\begin{abstract}
The wild mungbean, Vigna radiata ssp. sublobata, is an 'old world' tropical species indigenous throughout the better watered areas of northern Australia. Variation among 115 accessions, mainly from Australia, West Timor, and Papua New Guinea, was evaluated for several diverse traits. The plants were cultivated in the field at 2 sowing dates, at both a tropical and a subtropical location, with 6 accessions from India and a mungbean cultivar for comparison. Substantial variation was identified for traits of potential agronomic, adaptive, or taxonomic interest. For some traits, like phenology, the variation appeared to be systematic, with plausible underlying physiological and/or adaptive explanation. Among accessions, wild type traits, like prostrate habit, more gracile morphology, twining form, and small hard seeds, tended to be associated. There was a general geographic trend for lines collected from locations more remote from where mungbean has historically been cultivated to show greater expression of wild type traits, with few 'traits of domestication' evident in the Australian accessions. Some of the identified variation, e.g. higher seed protein content, hardseededness, and putative disease resistance, may be of value in mungbean variety improvement. A more targetted evaluation of the collection would likely reveal other adaptations, especially tolerance to environmental stresses. As such, the wild accessions are a potentially valuable if under-utilised germplasm resource.
\end{abstract}

Additional keywords: germplasm, plant improvement.

\section{Introduction}

The wild mungbean, Vigna radiata ssp. sublobata, the putative progenitor of the cultivated mungbean, V. radiata ssp. radiata, is an indigenous species throughout the moderate to higher rainfall areas of tropical and subtropical Australia (Lawn and Cottrell 1988). The species is widespread, ranging from southern Africa, across southern and eastern Asia, and the islands of Indonesia, Australia, and Papua New Guinea, as far east as western Oceania (Verdcourt 1970, 1979).

Over the past 2 decades, a large collection of accessions has been assembled and seed committed to long-term storage, as part of a systematic project to collect, describe, and conserve the several indigenous/endemic Vigna species in Australia (Lawn and Watkinson 2002). Included in the collection are more than 120 accessions of the wild mungbean, primarily from mainland Australia, but also from nearby islands of Indonesia and Papua New Guinea with a few from more remote locations including India.

The wild species represents a potentially useful adjunct to the germplasm of cultivated mungbean, by extending the range of variation available to breeders for traits of interest, notably pest resistance (e.g. Tomooka et al. 1992; Lambrides and Imrie 2000) and adaptations to the environment. The wider diversity has also proved useful in the development of molecular linkage maps for mungbean (Menancio-Hautea et al. 1992; Lambrides et al. 2000). To date, however, there has been relatively little quantitative information documented on the nature and extent of the variation in Australian accessions of ssp. sublobata.

Limited qualitative information, often based on few accessions, has suggested that the Australian material differs morphologically and genetically from other forms of spp. sublobata. For example, a recent molecular marker study of a diverse set of ssp. sublobata accessions by Saravanakumar et al. (2004) co-located 2 Australian accessions from Cape York at one extreme of the range of variation, together with 3 accessions from Papua New Guinea. Tateishi (1984) even disputed that the specimen collected by Banks and Solander at Endeavour River was ssp. sublobata, erroneously describing it as the Asian species V. reflexo-pilosa Hayata. 
This paper reports quantitative research to describe the nature and extent of genotypic variation among Australian accessions of the wild mungbean, for a range of traits of potential agronomic, adaptive, or taxonomic interest. The paper complements others by Grant et al. (2003) and Lawn and Holland (2003), documenting the collection and description of an extensive collection of Australian accessions of Vigna species.

\section{Materials and methods}

Plants of the accessions from Australia and nearby islands together with several accessions from India and one cultivar for comparison were grown in contrasting environments to document the expression of more than 30 traits of interest during plant growth.

\section{Germplasm}

A total of 121 accessions of diverse provenance was evaluated (Table 1), obtained from the collection described by Lawn and Watkinson (2002). The largest group comprised 97 accessions of ssp. sublobata collected across northern Australia, with smaller numbers obtained from West Timor (12), Papua New Guinea (4), and Madagascar and Taiwan (1 each). Each accession represented a collection from a specific location, in most cases comprising a mixture of seed from more than one plant, but in some cases, comprising seed from a single plant. Because the species is largely self-pollinating, individual accessions therefore generally comprise mixtures of closely related, but largely homozygous lines.

In addition, 6 roadside collections of ssp. sublobata from India (I. B. Staples, pers. comm., 1994) and the cultivar Satin were included for comparison. Satin is an erect, relatively synchronous-podding variety adapted to the eastern subtropics and suited to mechanical harvest (Lawn 1989b), and is a typical example of an improved cultivar of ssp. radiata.

\section{Experimental sites and sowings}

Four contrasting environments were obtained by growing the accessions at 2 sowing dates, early summer and late summer or autumn, at 2 sites, the CSIRO Pasture Research Stations at Samford ('the subtropics') and at Lansdown ('the tropics').

Climate and soils for the 2 sites are described in Cook and Russell (1983). Briefly, Samford $\left(27^{\circ} 22^{\prime} \mathrm{S}, 152^{\circ} 53^{\prime} \mathrm{E}\right.$; alt. $\left.56 \mathrm{~m}\right)$ is located in south-eastern Queensland on the flood plain of the South Pine River. The region is situated in the humid subtropics but cooler winter minimum temperatures give rise to a more continental climate. Rainfall is summerdominant, with $\sim 70 \%$ between October and March. The soil type is a deep, fertile, weakly structured, alluvial grey-brown silty loam. Lansdown $\left(19^{\circ} 36^{\prime} \mathrm{S}, 146^{\circ} 50^{\prime} \mathrm{E}\right.$; alt. $\left.61 \mathrm{~m}\right)$ is located $1400 \mathrm{~km}$ north of Samford on a flat to gently undulating plain. Climatically, the site is in the subhumid monsoon tropics, with $\sim 86 \%$ of the annual rainfall occurring between October and March. Soil type is a shallow, moderately structured, dark brown loam, of moderate fertility.

The 2 sowing dates at each location were selected to elicit differential responses among accessions to climatic conditions experienced during the summer and autumn periods. Sowings were therefore made on 9 December and 23 February in the subtropics and on 21 December and 5 April in the tropics. The April sowing at Lansdown was later than planned because of a drier than normal year, with drought during February and March. In contrast, the season was wetter than normal at Samford and the plants in the first sowing experienced transient waterlogging during vegetative growth.

\section{Cultural management}

Agronomic management was designed to ensure conditions generally favourable to plant growth, and minimise any confounding effects due to water supply, soil fertility, weed competition, or insect/disease damage. Soil tests indicated a high nutrient status at both sites, restricting the need for fertiliser to a basal mixture of $\mathrm{P}$ (as superphosphate at $40 \mathrm{~kg} / \mathrm{ha}$ ) and $\mathrm{Zn}$ (as $\mathrm{ZnSO}_{4}$ in heptahydrate form at $20 \mathrm{~kg} / \mathrm{ha}$ ). Both fertilisers were incorporated together with the pre-emergent herbicide trifluralin (at $0.9 \mathrm{~L} / \mathrm{ha}$ ) immediately prior to sowing. Seed was handscarified using a scalpel to remove a small portion of testa, then dusted with the fungicide thiram and hand-sown to a depth of $0.5 \mathrm{~cm}$. Seed was inoculated with a slurry of Bradyrhizobium sp. strain CB1015, and then covered and irrigated. Successful nodulation occurred in all sowings of all accessions. Irrigation was applied throughout the season as necessary.

Insecticides (dimethoate and diazinon) and fungicides (mancozeb and benomyl) were applied as necessary during plant growth. In the event, wet humid conditions in the subtropics resulted in severe outbreaks of the fungal leaf diseases, cercospora leaf spot (Cercospora canescens) and powdery mildew (Sphaerotheca fuliginea), and the bacterial leaf disease, halo blight (Psuedomonas syringae pv. phaseolicola). These were largely controlled but not eliminated by applications of fungicide, so that considerable leaf damage was still sustained by the most susceptible accessions.

\section{Experimental design}

Plants in each sowing were grown in $2 \mathrm{~m}$ by $2 \mathrm{~m}$ plots, arranged in a randomised complete block design with 2 replicates within each sowing. Individual plots comprised a single $1-\mathrm{m}$ row of plants centred in the plot to allow for the scrambling, prostrate habit of most of the accessions. Laterals extending beyond the plot borders later in the season were pruned regularly to prevent adjacent plots becoming intertwined. Borders comprising cv. Satin were sown around the external perimeters of each block. Seedlings were thinned to $0.1-\mathrm{m}$ intervals and a $1.3-\mathrm{m}$ wooden stake with a styrofoam cup affixed was driven into the sowing row of each plot to enable the regular collection of mature pods before they shattered.

\section{Traits recorded}

Phenology, biomass, seed yield, and selected pod and seed traits were recorded in all 4 environments. All other traits were measured in the first sowing in the subtropics and in as many of the other 3 environments as resources or circumstances (e.g. disease occurrence) permitted. Essential detail for each trait is described here, with additional detail available in Rebetzke (1994).

\section{Phenology}

Plots were observed every 2-3 days and the dates recorded for: emergence (when the cotyledons of $50 \%$ of seedlings had emerged); flowering (the appearance of first flowers on $50 \%$ of plants); end of flowering (when major flowering flushes ceased and only sporadic flowering persisted); the harvest of the first ripe pods; and physiological maturity ( $95 \%$ total seed yield). Durations of the respective phenological phases were calculated using these dates.

\section{Pod and seed traits}

The number of seeds per pod, seed size (100-seed weight), and pod length $(\mathrm{mm})$ were measured from a sample of pods recovered from the first 3-4 harvests for each accession in each of the 4 environments. Seed protein content and levels of hardseededness were estimated for the first sowings only at both sites, using seeds from the first-harvested mature pods from each plot. For the protein estimates, a standard Kjeldahl analysis (Johnson et al. 1985) was used to measure total seed 
Table 1. Provenance of accessions of wild mungbean ( . radiata ssp. sublobata) evaluated in the present study ACC, National Vigna Collection Accession number (Lawn and Watkinson 2002)

\begin{tabular}{|c|c|c|c|c|}
\hline Accession & Location & Latitude & Longitude & Altitude (m) \\
\hline \multicolumn{5}{|c|}{ Australian accessions } \\
\hline ACC 1 & Slade Point, Mackay & $21^{\circ} 10^{\prime} \mathrm{S}$ & $149^{\circ} 10^{\prime} \mathrm{E}$ & 1 \\
\hline ACC 2 & Castle Hill, Townsville & $19^{\circ} 13^{\prime} \mathrm{S}$ & $146^{\circ} 48^{\prime} \mathrm{E}$ & 100 \\
\hline ACC 3 & Magnetic Island & $18^{\circ} 12^{\prime} \mathrm{S}$ & $147^{\circ} 25^{\prime} \mathrm{E}$ & 2 \\
\hline $\mathrm{ACC} 4$ & Near Walkamin & $17^{\circ} 02^{\prime} \mathrm{S}$ & $145^{\circ} 32^{\prime} \mathrm{E}$ & 500 \\
\hline ACC 5 & Tinaroo Dam & $17^{\circ} 01^{\prime} \mathrm{S}$ & $145^{\circ} 30^{\prime} \mathrm{E}$ & 500 \\
\hline ACC 6 & Mt Molloy-Mareeba Rd & $16^{\circ} 37^{\prime} \mathrm{S}$ & $145^{\circ} 23^{\prime} \mathrm{E}$ & 500 \\
\hline $\mathrm{ACC} 7$ & Boggy Creek, Cooktown Rd & $15^{\circ} 50^{\prime} \mathrm{S}$ & $144^{\circ} 59^{\prime} \mathrm{E}$ & 250 \\
\hline ACC 8 & Black Mountain Park & $15^{\circ} 40^{\prime} \mathrm{S}$ & $145^{\circ} 08^{\prime} \mathrm{E}$ & 100 \\
\hline ACC 9 & Endeavour River, Cooktown & $15^{\circ} 29^{\prime} \mathrm{S}$ & $145^{\circ} 15^{\prime} \mathrm{E}$ & 1 \\
\hline $\mathrm{ACC} 10$ & Cooktown & $15^{\circ} 29^{\prime} \mathrm{S}$ & $145^{\circ} 15^{\prime} \mathrm{E}$ & 2 \\
\hline ACC 11 & Cooktown & $15^{\circ} 29^{\prime} \mathrm{S}$ & $145^{\circ} 15^{\prime} \mathrm{E}$ & 2 \\
\hline ACC 12 & Port Douglas & $16^{\circ} 35^{\prime} \mathrm{S}$ & $145^{\circ} 29^{\prime} \mathrm{E}$ & 0 \\
\hline $\mathrm{ACC} 13$ & Ibilbie & $21^{\circ} 30^{\prime} \mathrm{S}$ & $149^{\circ} 15^{\prime} \mathrm{E}$ & 20 \\
\hline $\mathrm{ACC} 14$ & Peak Downs & $22^{\circ} 14^{\prime} \mathrm{S}$ & $148^{\circ} 09^{\prime} \mathrm{E}$ & 250 \\
\hline ACC 15 & Kununurra & $15^{\circ} 42^{\prime} \mathrm{S}$ & $128^{\circ} 50^{\prime} \mathrm{E}$ & 100 \\
\hline $\mathrm{ACC} 16$ & Douglas/Daly region & $13^{\circ} 42^{\prime} \mathrm{S}$ & $131^{\circ} 18^{\prime} \mathrm{E}$ & 200 \\
\hline $\mathrm{ACC} 17$ & Douglas/Daly region & $13^{\circ} 42^{\prime} \mathrm{S}$ & $131^{\circ} 18^{\prime} \mathrm{E}$ & 200 \\
\hline ACC 18 & Douglas/Daly region & $13^{\circ} 42^{\prime} \mathrm{S}$ & $131^{\circ} 18^{\prime} \mathrm{E}$ & 200 \\
\hline ACC 19 & Douglas/Daly region & $13^{\circ} 42^{\prime} \mathrm{S}$ & $131^{\circ} 18^{\prime} \mathrm{E}$ & 200 \\
\hline ACC 20 & Kununurra & $15^{\circ} 42^{\prime} \mathrm{S}$ & $128^{\circ} 50^{\prime} \mathrm{E}$ & 100 \\
\hline ACC 21 & Ooloo Station, NT & $13^{\circ} 47^{\prime} \mathrm{S}$ & $131^{\circ} 12^{\prime} \mathrm{E}$ & 200 \\
\hline ACC 22 & Keelbottom Creek, Hervey's Range & $19^{\circ} 35^{\prime} \mathrm{S}$ & $146^{\circ} 17^{\prime} \mathrm{E}$ & 400 \\
\hline ACC 23 & South of Sarina & $21^{\circ} 35^{\prime} \mathrm{S}$ & $149^{\circ} 15^{\prime} \mathrm{E}$ & 20 \\
\hline ACC 24 & Near The Lynd & $18^{\circ} 40^{\prime} \mathrm{S}$ & $144^{\circ} \mathrm{I} 8^{\prime} \mathrm{E}$ & 550 \\
\hline ACC 25 & Fanning River & $19^{\circ} 44^{\prime} \mathrm{S}$ & $146^{\circ} 26^{\prime} \mathrm{E}$ & 250 \\
\hline ACC 26 & Mingela Range & $19^{\circ} 53^{\prime} \mathrm{S}$ & $146^{\circ} 40^{\prime} \mathrm{E}$ & 200 \\
\hline ACC 27 & Boomerang & $18^{\circ} 14^{\prime} \mathrm{S}$ & $144^{\circ} 51^{\prime} \mathrm{E}$ & 600 \\
\hline ACC 28 & Captain Billy & $11^{\circ} 39^{\prime} \mathrm{S}$ & $142^{\circ} 51^{\prime} \mathrm{E}$ & 10 \\
\hline $\mathrm{ACC} 29$ & Captain Billy & $11^{\circ} 39^{\prime} \mathrm{S}$ & $142^{\circ} 51^{\prime} \mathrm{E}$ & 10 \\
\hline $\operatorname{ACC} 30^{A}$ & 'Cape York' & - & - & - \\
\hline ACC 31 & Musgrave & $14^{\circ} 35^{\prime} \mathrm{S}$ & $143^{\circ} 31^{\prime} \mathrm{E}$ & 190 \\
\hline ACC 32 & Plains Station, Tabulam & $28^{\circ} 53^{\prime} \mathrm{S}$ & $152^{\circ} 34^{\prime} \mathrm{E}$ & 150 \\
\hline ACC 33 & Sunday Creek Station & $16^{\circ} 13^{\prime} \mathrm{S}$ & $133^{\circ} 03^{\prime} \mathrm{E}$ & 200 \\
\hline ACC 34 & Sunday Creek Station & $16^{\circ} 13^{\prime} \mathrm{S}$ & $133^{\circ} 03^{\prime} \mathrm{E}$ & 200 \\
\hline ACC 35 & Emerald & $23^{\circ} 29^{\prime} \mathrm{S}$ & $148^{\circ} 09^{\prime} \mathrm{E}$ & 180 \\
\hline ACC 36 & Normanton-Karumba Rd & $17^{\circ} 25^{\prime} \mathrm{S}$ & $140^{\circ} 52^{\prime} \mathrm{E}$ & 10 \\
\hline ACC 37 & Yirrkala, Gove & $12^{\circ} 15^{\prime} \mathrm{S}$ & $136^{\circ} 53^{\prime} \mathrm{E}$ & 3 \\
\hline ACC 38 & Emerald & $23^{\circ} 29^{\prime} \mathrm{S}$ & $148^{\circ} 09^{\prime} \mathrm{E}$ & 180 \\
\hline ACC 39 & Emerald-Springsure Rd & $23^{\circ} 40^{\prime} \mathrm{S}$ & $148^{\circ} 10^{\prime} \mathrm{E}$ & 210 \\
\hline $\mathrm{ACC} 40$ & Murray Island, Torres Strait & $9^{\circ} 55^{\prime} \mathrm{S}$ & $144^{\circ} 05^{\prime} \mathrm{E}$ & 1 \\
\hline $\mathrm{ACC} 41$ & Somerset Dam & $27^{\circ} 07^{\prime} \mathrm{S}$ & $152^{\circ} 33^{\prime} \mathrm{E}$ & 170 \\
\hline ACC 46 & Riverview Station, Burdekin & $20^{\circ} 00^{\prime} \mathrm{S}$ & $147^{\circ} 20^{\prime} \mathrm{E}$ & 120 \\
\hline $\operatorname{ACC} 47^{\mathrm{A}}$ & 'Queensland' & - & - & - \\
\hline ACC 48 & Douglas/Daly Research Station & $13^{\circ} 50^{\prime} \mathrm{S}$ & $131^{\circ} 11^{\prime} \mathrm{E}$ & 150 \\
\hline ACC 49 & Sunday Creek Station & $16^{\circ} 15^{\prime} \mathrm{S}$ & $133^{\circ} 03^{\prime} \mathrm{E}$ & 10 \\
\hline ACC 50 & Sunday Creek Station & $16^{\circ} 15^{\prime} \mathrm{S}$ & $133^{\circ} 03^{\prime} \mathrm{E}$ & 210 \\
\hline ACC 51 & Sunday Creek Station & $16^{\circ} 15^{\prime} \mathrm{S}$ & $133^{\circ} 03^{\prime} \mathrm{E}$ & 210 \\
\hline ACC 52 & Sunday Creek Station & $16^{\circ} 15^{\prime} \mathrm{S}$ & $133^{\circ} 03^{\prime} \mathrm{E}$ & 210 \\
\hline ACC 53 & Sunday Creek Station & $16^{\circ} 15^{\prime} \mathrm{S}$ & $133^{\circ} 03^{\prime} \mathrm{E}$ & 210 \\
\hline ACC 56 & Habana Wharf & $20^{\circ} 59^{\prime} \mathrm{S}$ & $149^{\circ} 05^{\prime} \mathrm{E}$ & 1 \\
\hline ACC 57 & Slade Point, Mackay & $21^{\circ} 10^{\prime} \mathrm{S}$ & $149^{\circ} 10^{\prime} \mathrm{E}$ & 50 \\
\hline ACC 58 & Eungella Dam & $21^{\circ} 08^{\prime} \mathrm{S}$ & $148^{\circ} 23^{\prime} \mathrm{E}$ & 550 \\
\hline ACC 59 & Mt Martin, Mirani & $21^{\circ} 05^{\prime} \mathrm{S}$ & $148^{\circ} 41^{\prime} \mathrm{E}$ & 200 \\
\hline $\mathrm{ACC} 60$ & Ayr-Clare Rd & $19^{\circ} 40^{\prime} \mathrm{S}$ & $147^{\circ} 21^{\prime} \mathrm{E}$ & 10 \\
\hline ACC 70 & Douglas/Daly region & $13^{\circ} 32^{\prime} \mathrm{S}$ & $131^{\circ} 12^{\prime} \mathrm{E}$ & 180 \\
\hline ACC 71 & Douglas/Daly region & $13^{\circ} 32^{\prime} \mathrm{S}$ & $131^{\circ} 12^{\prime} \mathrm{E}$ & 180 \\
\hline ACC 72 & Borumba Dam, Imbil & $26^{\circ} 31^{\prime} \mathrm{S}$ & $152^{\circ} 35^{\prime} \mathrm{E}$ & 200 \\
\hline \multirow[t]{2}{*}{ ACC 73} & Woodstock-Giru Rd & $19^{\circ} 33^{\prime} \mathrm{S}$ & $147^{\circ} 03^{\prime} \mathrm{E}$ & 160 \\
\hline & & & & led next page) \\
\hline
\end{tabular}


Table 1. (continued)

\begin{tabular}{|c|c|c|c|c|}
\hline Accession & Location & Latitude & Longitude & Altitude (m) \\
\hline ACC 75 & West of Top Springs, NT & $16^{\circ} 22^{\prime} \mathrm{S}$ & $131^{\circ} 12^{\prime} \mathrm{E}$ & 180 \\
\hline ACC 76 & Victoria River & $16^{\circ} 21^{\prime} \mathrm{S}$ & $131^{\circ} 05^{\prime} \mathrm{E}$ & 190 \\
\hline ACC 77 & Victoria River Downs & $16^{\circ} 14^{\prime} \mathrm{S}$ & $130^{\circ} 57^{\prime} \mathrm{E}$ & 195 \\
\hline ACC 78 & Buchanan Highway, NT & $15^{\circ} 52^{\prime} \mathrm{S}$ & $130^{\circ} 34^{\prime} \mathrm{E}$ & 185 \\
\hline ACC 79 & Timber Creek & $15^{\circ} 38^{\prime} \mathrm{S}$ & $130^{\circ} 23^{\prime} \mathrm{E}$ & 180 \\
\hline ACC 80 & West of Katherine & $15^{\circ} 04^{\prime} \mathrm{S}$ & $131^{\circ} 44^{\prime} \mathrm{E}$ & 190 \\
\hline ACC 83 & Dalbeg & $20^{\circ} 19^{\prime} \mathrm{S}$ & $147^{\circ} 22^{\prime} \mathrm{E}$ & 50 \\
\hline ACC 84 & Near Ayr & $19^{\circ} 30^{\prime} \mathrm{S}$ & $147^{\circ} 26^{\prime} \mathrm{E}$ & 2 \\
\hline ACC 85 & Alva Beach & $19^{\circ} 28^{\prime} \mathrm{S}$ & $147^{\circ} 29^{\prime} \mathrm{E}$ & 2 \\
\hline ACC 86 & Clare & $19^{\circ} 28^{\prime} \mathrm{S}$ & $147^{\circ} 13^{\prime} \mathrm{E}$ & 25 \\
\hline ACC 87 & Near Lansdown & $19^{\circ} 42^{\prime} \mathrm{S}$ & $146^{\circ} 50^{\prime} \mathrm{E}$ & 170 \\
\hline $\mathrm{ACC} 87 \mathrm{~S}^{\mathrm{B}}$ & Near Lansdown & $19^{\circ} 42^{\prime} \mathrm{S}$ & $146^{\circ} 50^{\prime} \mathrm{E}$ & 170 \\
\hline ACC 88 & Mingela Range & $19^{\circ} 53^{\prime} \mathrm{S}$ & $146^{\circ} 32^{\prime} \mathrm{E}$ & 200 \\
\hline ACC 89 & Mingela-Ravenswood Rd & $19^{\circ} 56^{\prime} \mathrm{S}$ & $146^{\circ} 42^{\prime} \mathrm{E}$ & 200 \\
\hline ACC 90 & Charters Towers & $20^{\circ} 03^{\prime} \mathrm{S}$ & $146^{\circ} 18^{\prime} \mathrm{E}$ & 250 \\
\hline ACC 91 & Near Townsville & $19^{\circ} 21^{\prime} \mathrm{S}$ & $146^{\circ} 52^{\prime} \mathrm{E}$ & 10 \\
\hline ACC 92 & Hillsborough Stud Station & $20^{\circ} 02^{\prime} \mathrm{S}$ & $147^{\circ} 00^{\prime} \mathrm{E}$ & 100 \\
\hline ACC 93 & Murray Island & $9^{\circ} 55^{\prime} \mathrm{S}$ & $144^{\circ} 05^{\prime} \mathrm{E}$ & 2 \\
\hline ACC 94 & Berrimah Junction & $12^{\circ} 32^{\prime} \mathrm{S}$ & $131^{\circ} 03^{\prime} \mathrm{E}$ & 0 \\
\hline ACC 95 & Katherine & $14^{\circ} 27^{\prime} \mathrm{S}$ & $132^{\circ} 12^{\prime} \mathrm{E}$ & 190 \\
\hline ACC 96 & Douglas/Daly region & $13^{\circ} 35^{\prime} \mathrm{S}$ & $131^{\circ} 26^{\prime} \mathrm{E}$ & 180 \\
\hline ACC 97 & Douglas/Daly Research Station & $13^{\circ} 50^{\prime} \mathrm{S}$ & $131^{\circ} 11^{\prime} \mathrm{E}$ & 180 \\
\hline ACC 98 & Stuart Highway & $13^{\circ} 27^{\prime} \mathrm{S}$ & $131^{\circ} 20^{\prime} \mathrm{E}$ & 10 \\
\hline ACC 99 & Duncan Highway, Kimberley & $15^{\circ} 47^{\prime} \mathrm{S}$ & $128^{\circ} 33^{\prime} \mathrm{E}$ & 100 \\
\hline ACC 100 & Turkey Creek & $15^{\circ} 54^{\prime} \mathrm{S}$ & $128^{\circ} 21^{\prime} \mathrm{E}$ & 190 \\
\hline ACC 101 & Wyndham turnoff, Kimberley & $17^{\circ} 05^{\prime} \mathrm{S}$ & $128^{\circ} 12^{\prime} \mathrm{E}$ & 190 \\
\hline ACC 102 & Great Northern Highway & $17^{\circ} 24^{\prime} \mathrm{S}$ & $128^{\circ} 02^{\prime} \mathrm{E}$ & 190 \\
\hline ACC 103 & Halls Creek & $18^{\circ} 02^{\prime} \mathrm{S}$ & $127^{\circ} 48^{\prime} \mathrm{E}$ & 350 \\
\hline ACC 104 & Fitzroy Crossing & $18^{\circ} 05^{\prime} \mathrm{S}$ & $125^{\circ} 23^{\prime} \mathrm{E}$ & 350 \\
\hline ACC 105 & King Leopold Range & $17^{\circ} 16^{\prime} \mathrm{S}$ & $124^{\circ} 51^{\prime} \mathrm{E}$ & 350 \\
\hline ACC 106 & Yates Creek, Gibb River Rd & $17^{\circ} 09^{\prime} \mathrm{S}$ & $124^{\circ} 58^{\prime} \mathrm{E}$ & 350 \\
\hline ACC 107 & Mt Hart Station, Gibb River Rd & $17^{\circ} 07^{\prime} \mathrm{S}$ & $125^{\circ} 12^{\prime} \mathrm{E}$ & 190 \\
\hline ACC 108 & Mt House Station, Gibb River Rd & $17^{\circ} 09^{\prime} \mathrm{S}$ & $125^{\circ} 28^{\prime} \mathrm{E}$ & 190 \\
\hline ACC 109 & Mt House Station, Gibb River Rd & $16^{\circ} 59^{\prime} \mathrm{S}$ & $125^{\circ} 40^{\prime} \mathrm{E}$ & 190 \\
\hline ACC 110 & Station Creek, Gibb River Rd & $16^{\circ} 43^{\prime} \mathrm{S}$ & $125^{\circ} 56^{\prime} \mathrm{E}$ & 100 \\
\hline ACC 111 & Pentecost River, Gibb River Rd & $15^{\circ} 53^{\prime} \mathrm{S}$ & $128^{\circ} 13^{\prime} \mathrm{E}$ & 100 \\
\hline ACC 112 & Maggie Ck, Wyndham & $15^{\circ} 37^{\prime} \mathrm{S}$ & $128^{\circ} 15^{\prime} \mathrm{E}$ & 10 \\
\hline ACC 113 & Six Mile Ck, Wyndham & $15^{\circ} 28^{\prime} \mathrm{S}$ & $128^{\circ} 07^{\prime} \mathrm{E}$ & 10 \\
\hline $\mathrm{ACC} 114$ & Millaroo & $20^{\circ} 03^{\prime} \mathrm{S}$ & $147^{\circ} 16^{\prime} \mathrm{E}$ & 35 \\
\hline \multicolumn{5}{|c|}{ Exotic accessions } \\
\hline \multicolumn{5}{|c|}{ West Timor, Indonesia } \\
\hline ACC 61 & CPI $^{\mathrm{C}} 106929$ Besi Pae Complex & $10^{\circ} 00^{\prime} \mathrm{S}$ & $124^{\circ} 10^{\prime} \mathrm{E}$ & 100 \\
\hline ACC 62 & CPI 106930 Around Kupang & $10^{\circ} 10^{\prime} \mathrm{S}$ & $123^{\circ} 34^{\prime} \mathrm{E}$ & 25 \\
\hline ACC 63 & CPI 106931 Near Kupang & $10^{\circ} 10^{\prime} \mathrm{S}$ & $123^{\circ} 34^{\prime} \mathrm{E}$ & 15 \\
\hline ACC 64 & CPI 106932 Near Kupang & $10^{\circ} 10^{\prime} \mathrm{S}$ & $123^{\circ} 34^{\prime} \mathrm{E}$ & 15 \\
\hline ACC 65 & CPI 106933 Kefamenanu & $9^{\circ} 29^{\prime} \mathrm{S}$ & $124^{\circ} 30^{\prime} \mathrm{E}$ & 300 \\
\hline ACC 66 & CPI 106934 Aroki Plain, Atambua & $9^{\circ} 27^{\prime} \mathrm{S}$ & $124^{\circ} 46^{\prime} \mathrm{E}$ & 300 \\
\hline ACC 67 & CPI 106935 South of Kefamenanu & $9^{\circ} 31^{\prime} \mathrm{S}$ & $124^{\circ} 34^{\prime} \mathrm{E}$ & 300 \\
\hline ACC 68 & CPI 106939 Badlands, Besi Pae & $10^{\circ} 00^{\prime} \mathrm{S}$ & $124^{\circ} 10^{\prime} \mathrm{E}$ & 35 \\
\hline ACC 69 & CPI 105033 Binel & $10^{\circ} 00^{\prime} \mathrm{S}$ & $124^{\circ} 10^{\prime} \mathrm{E}$ & 50 \\
\hline $\mathrm{ACC} 74$ & CPI 107220 Kupang & $10^{\circ} 10^{\prime} \mathrm{S}$ & $123^{\circ} 34^{\prime} \mathrm{E}$ & 15 \\
\hline $\mathrm{ACC} 81^{\mathrm{D}}$ & CPI 109126 Besi Pae & $10^{\circ} 00^{\prime} \mathrm{S}$ & $124^{\circ} 10^{\prime} \mathrm{E}$ & 100 \\
\hline ACC 82 & CPI 109127 Besi Pae & $10^{\circ} 00^{\prime} \mathrm{S}$ & $124^{\circ} 10^{\prime} \mathrm{E}$ & 100 \\
\hline \multicolumn{5}{|c|}{ Papua-New Guinea } \\
\hline ACC 42 & CPI 100762 Kila Kila, Port Moresby & $9^{\circ} 31^{\prime} \mathrm{S}$ & $147^{\circ} 07^{\prime} \mathrm{E}$ & 70 \\
\hline ACC 43 & CPI 100771 South of Port Moresby & $9^{\circ} 30^{\prime} \mathrm{S}$ & $147^{\circ} 07^{\prime} \mathrm{E}$ & - \\
\hline $\mathrm{ACC} 44$ & CPI 100816 West of Erap & $6^{\circ} 35^{\prime} \mathrm{S}$ & $146^{\circ} 43^{\prime} \mathrm{E}$ & 70 \\
\hline $\mathrm{ACC} 45$ & CPI 100834 East of Bogia & $4^{\circ} 16^{\prime} \mathrm{S}$ & $144^{\circ} 56^{\prime} \mathrm{E}$ & 10 \\
\hline
\end{tabular}


Table 1. (continued)

\begin{tabular}{|c|c|c|c|c|}
\hline Accession & Location & Latitude & Longitude & Altitude (m) \\
\hline \multicolumn{5}{|l|}{ Other } \\
\hline ACC $54^{\mathrm{E}}$ & CPI 101009 Madagascar & - & - & - \\
\hline $\mathrm{ACC} 55^{\mathrm{E}}$ & CPI 101011 Taiwan & - & - & - \\
\hline \multicolumn{5}{|l|}{ India } \\
\hline ACC 115 & CPI 106261 Nalgoda, Andhra Pradesh & $16^{\circ} 58^{\prime} \mathrm{N}$ & $79^{\circ} 17^{\prime} \mathrm{E}$ & 230 \\
\hline ACC 116 & CPI 106273 Macherla, Andhra Pradesh & $16^{\circ} 17^{\prime} \mathrm{N}$ & $79^{\circ} 19^{\prime} \mathrm{E}$ & 240 \\
\hline ACC $117 \mathrm{~A}^{\mathrm{F}}$ & CPI 106032 Madhura & $19^{\circ} 49^{\prime} \mathrm{N}$ & $77^{\circ} 10^{\prime} \mathrm{E}$ & 530 \\
\hline $\mathrm{ACC} 117 \mathrm{~B}^{\mathrm{F}}$ & CPI 106032 Madhura & $19^{\circ} 49^{\prime} \mathrm{N}$ & $76^{\circ} 10^{\prime} \mathrm{E}$ & 530 \\
\hline ACC 118 & CPI 106046 Akoli, Maharashtra & $19^{\circ} 35^{\prime} \mathrm{N}$ & $76^{\circ} 18^{\prime} \mathrm{E}$ & 420 \\
\hline ACC 119 & CPI 106815 Vellar River, Madras Rd & $11^{\circ} 25^{\prime} \mathrm{N}$ & $79^{\circ} 01^{\prime} \mathrm{E}$ & 120 \\
\hline \multicolumn{5}{|l|}{ Cultivar } \\
\hline cv. Satin & Australian cultivar derived from hybrid 1 & dian and $\mathrm{P}$ & germplasm ( & \\
\hline
\end{tabular}

${ }^{\mathrm{A}}$ Exact provenance unknown.

${ }^{B}$ Shiny-seeded form of ACC 87.

${ }^{\mathrm{C}}$ Commonwealth Plant Introduction number.

${ }^{\mathrm{D}}$ Mixture of green and black seeds.

${ }^{\mathrm{E}}$ Ex Asian Vegetable Research \& Development Centre collection.

F ACC 117A, green-seeded form; ACC 117B, dark-seeded form.

nitrogen $(\mathrm{N})$, from which protein content $(\% \mathrm{w} / \mathrm{w})$ was estimated as $6.25 \times \mathrm{N}$. Levels of hardseededness were determined after exposing 100 seed samples to conditions favourable to germination for a period of $72 \mathrm{~h}$.

\section{Morphological traits}

Seedling traits recorded included seedling height, defined as the distance from the soil surface to the primary node and measured after expansion of the first trifoliolate leaf; the length and breadth of the primary leaf, and primary leaf shape, defined as the length to breadth ratio; and the intensity of anthocyanin pigment $(0$, absent; to 3 , very intense) below and above the cotyledons on the seedling stem. Vegetative traits included leaflet length, width, and length to width ratio (measured on the terminal leaflet of the 4th fully expanded trifoliolate leaf); leaflet lobing score, rated from 0 (leaves entire) to 5 (deeply scalloped leaflets with pronounced basal lobes); stem diameter (measured on the internode below the 4th fully expanded trifoliolate leaf); and the length, width, and length to width ratio of the stipule at node 4 .

Other traits included the width of the floral standard, plant growth habit [as a rating from 1 (erect) to 4 (prostrate)] made 8 weeks after sowing, and the presence or absence of stem twining on the wooden stakes in the plots. Evidence of perennial habit was determined by excavating the plant roots 6 weeks after the removal of the above-ground biomass and examining them for survival, and the presence of thickening and/or adventitious shoots.

\section{Biomass and seed yield}

Total standing dry matter was estimated for each plot following the last pod harvest. The standing biomass was removed and dried at $60^{\circ} \mathrm{C}$ for $96 \mathrm{~h}$. Pod biomass and seed yields per plot were calculated using the cumulative weekly harvests of pod and seeds. Total above-ground dry matter production (TDM) was then calculated as the sum of the several components. Harvest index (HI) was calculated as the ratio of seed yield to TDM.

\section{Disease incidence}

Opportunistic ratings of the severity of incidence of 3 economic diseases of mungbean, the fungal leaf diseases powdery mildew and cercospora leaf spot and the bacterial leaf disease halo blight, were made in the 2 sowings in the subtropics. Severity ratings ranged from 0 (no disease symptoms) to $3(50-100 \%$ of the leaf surface infected with lesions).

\section{Data analysis}

The primary statistical aim was to obtain information on the genotypic variation in the collection for each of the traits of interest. Initially, comparisons were made using analysis of variance between and within the 3 different germplasm groups, viz. the wild accessions of ssp. sublobata from Australia and nearby islands ('Austronesian group'), the Indian accessions of ssp. sublobata ('Indian group'), and the cv. Satin.

For a subset of 108 of the Austronesian accessions for which data were available from both sowings at both sites, estimates of the relative magnitudes of accession $(\mathrm{G})$ and accession $\times$ environment $(\mathrm{G} \times \mathrm{E})$ effects were made for several traits. In addition, as a measure of the repeatability of performance across environments for selected agronomic traits, broad-sense heritability was calculated on an entrymean basis using estimated variance components. The square root of the genotypic variance was used to estimate the accession coefficient of variation (Hallauer and Miranda 1988), to provide a measure of the dispersion of accession values and allow comparisons of variation among accessions for different traits.

Finally, for the wild accessions, correlations were used to explore inter-relations between traits, and between the expression of traits and the provenance of the accession.

\section{Results and discussion}

\section{Genotypic variation in traits}

The means for the 3 germplasm groups, and the ranges among accessions for the 2 ssp. sublobata groups, for several traits of potential agronomic, adaptive, or taxonomic interest, are shown in Table 2. Additional information on the variation for selected traits among accessions within 
Table 2. Comparisons for selected traits between Austronesian and Indian accessions of $V$. radiata ssp. sublobata, and a modern cultivar of $V$. radiata spp. radiata

Means for each trait, averaged as relevant over environment and sowing time, are shown for each germplasm group. Also shown are the ranges (in parentheses) among the 2 groups of wild accessions

\begin{tabular}{|c|c|c|c|c|}
\hline \multirow[t]{2}{*}{ Trait } & \multicolumn{2}{|c|}{ ssp. sublobata } & \multirow{2}{*}{$\begin{array}{l}\text { ssp. radiata } \\
\text { cv. Satin }\end{array}$} & \multirow[t]{2}{*}{ s.e. $^{\mathrm{A}}$} \\
\hline & Austronesian & Indian & & \\
\hline \multicolumn{5}{|c|}{ Phenology } \\
\hline Flowering (days) & $80.5(47.4-120.1)$ & $82.9(54.6-104.3)$ & 44.0 & $1.8^{* * *}$ \\
\hline Duration of reproductive growth (days) & $59.9(40.4-88.3)$ & $64.4(52.0-91.4)$ & 51.2 & $3.3 * * *$ \\
\hline Growth cycle (days) & $137(113-179)$ & $145(137-156)$ & 96 & $2.7 * * *$ \\
\hline \multicolumn{5}{|c|}{ Pod and seed traits } \\
\hline Seed size $(g / 100$ seed $)$ & $1.34(0.74-2.70)$ & $2.58(2.38-2.96)$ & 6.76 & $0.07 * * *$ \\
\hline Seeds per pod & $11.5(9.2-14.2)$ & $12.7(11.9-13.1)$ & 12.5 & $0.37 * * *$ \\
\hline Pod length (mm) & $55.0(40.0-69.1)$ & $60.7(57.7-67.6)$ & 89.2 & $2.15 * * *$ \\
\hline Seed protein $(\% \mathrm{w} / \mathrm{w})$ & $28.2(23.7-31.4)$ & $27.0(25.4-28.1)$ & 28.8 & $0.72 * *$ \\
\hline Hardseededness (\%) & $89(22-100)$ & $31(8-89)$ & 0 & $7.7 * * *$ \\
\hline \multicolumn{5}{|c|}{ Morphological traits } \\
\hline Height to primary node (mm) & $23.5(10.7-44.6)$ & $26.8(20.5-32.5)$ & 57.4 & $2.04 * * *$ \\
\hline \multicolumn{5}{|l|}{ Primary leaf size $\&$ shape } \\
\hline Length $(\mathrm{mm})$ & $23.3(14.6-33.4)$ & $37.0(31.0-41.2)$ & 50.3 & $2.6^{* * *}$ \\
\hline Breadth $(\mathrm{mm})$ & $11.4(5.4-19.6)$ & $15.3(13.0-19.0)$ & 25.2 & $2.5^{* * *}$ \\
\hline Length to breadth ratio & $2.65(1.5-6.2)$ & $2.77(2.3-3.2)$ & 2.40 & $0.42 \mathrm{n} . \mathrm{s}$. \\
\hline \multicolumn{5}{|l|}{ Terminal leaflet size $\&$ shape } \\
\hline Length (mm) & $64(49.6-79.8)$ & $77(70.8-82.9)$ & 103 & $4.1 * * *$ \\
\hline Width $(\mathrm{mm})$ & $52(37.8-75.0)$ & $70(65.0-83.8)$ & 95 & $4.3 * * *$ \\
\hline Length to width ratio & $1.31(0.99-1.90)$ & $1.13(0.99-1.22)$ & 1.10 & $0.06^{* * *}$ \\
\hline Leaf lobing score $(0-5)$ & $1.91(0-4.3)$ & $0.78(0.2-1.9)$ & 0 & $0.28 * * *$ \\
\hline \multicolumn{5}{|l|}{ Anthocyanin scores } \\
\hline Presence $(0-2)$ & $1.85(0.5-2.0)$ & $1.00(0-2.0)$ & 2.00 & $0.23 * * *$ \\
\hline Intensity below cotyledons $(0-3)$ & $2.24(0-3.0)$ & $1.25(0-2.0)$ & 3.0 & $0.39 * * *$ \\
\hline Intensity above cotyledons $(0-3)$ & $1.43(0-2.5)$ & $0.25(0-1.5)$ & 1.0 & $0.42 * * *$ \\
\hline Stem diam. above 4 th trifolioliate $(\mathrm{mm})$ & $4.9(3.1-6.5)$ & $7.5(6.7-8.4)$ & 7.1 & $0.41 * * *$ \\
\hline \multicolumn{5}{|l|}{ Stipules } \\
\hline Length (mm) & $9.3(7.1-12.2)$ & $10.8(8.2-12.3)$ & 10.2 & $0.62 * * *$ \\
\hline Width (mm) & $4.7(3.3-6.8)$ & $5.7(4.9-7.0)$ & 7.4 & $0.29 * * *$ \\
\hline Length to width ratio & $1.96(1.6-2.6)$ & $1.86(1.6-2.0)$ & 1.78 & $0.102 * * *$ \\
\hline Width of floral standard (mm) & $13.3(6.0-18.0)$ & $15.4(13.4-16.7)$ & 14.9 & $0.77 * * *$ \\
\hline Habit $(1-4)$ & $3.4(2.6-4.0)$ & $2.1(1.4-2.8)$ & 1.4 & $0.21 * * *$ \\
\hline Twining $(0-1)$ & $0.99(0.75-1.0)$ & $0.27(0-1.0)$ & 0 & $0.033^{* *}$ \\
\hline \multicolumn{5}{|c|}{ Biomass and seed yield } \\
\hline Total dry matter $\left(\mathrm{g} / \mathrm{m}^{2}\right)$ & $221(107-356)$ & $315(220-365)$ & 662 & $24 * * *$ \\
\hline Seed yield $\left(\mathrm{g} / \mathrm{m}^{2}\right)$ & $18.4(0.3-83.3)$ & $35.9(12.1-56.9)$ & 243.5 & $7.1 * * *$ \\
\hline Harvest index & $0.08(0.01-0.24)$ & $0.12(0.03-0.18)$ & 0.33 & $0.014 * * *$ \\
\hline \multicolumn{5}{|c|}{ Disease reaction $(0-3)$} \\
\hline Cercospora leaf spot rating & $0.74(0-2.58)$ & $0.23(0-0.65)$ & 0.48 & $0.214 * * *$ \\
\hline Powdery mildew rating & $0.25(0-2.0)$ & $0(0)$ & 0.19 & $0.12 *$ \\
\hline Halo blight rating & $0.40(0-1.6)$ & $0.19(0-0.75)$ & 0 & $0.244 * *$ \\
\hline
\end{tabular}

n.s., Not significant $(P>0.05) ; * P \leq 0.05 ; * * P \leq 0.01 ; * * * P \leq 0.001$.

${ }^{\text {A }}$ For differences among the 3 germplasm groups.

the Austronesian group is presented in Table 3 and Fig. 1. For most traits, there were significant differences between one or more of the germplasm groups, notwithstanding considerable inter-accession variation within the 2 ssp. sublobata groups.

\section{Phenology}

The growth duration of both groups of wild accessions was consistently longer than for cv. Satin (Table 2). Even the earliest maturing of the wild types was more than 2 weeks later maturing than the cultivar. In large part, the difference 
Table 3. Variation in selected traits among accessions of ssp. sublobata from Australia and nearby islands

Identified for each trait are those accessions (cf. Table 1) with values close to the minimum and maximum accession values (cf. Table 2), averaged as relevant over sowing dates and locations, the standard deviation $(\sigma)$ and the coefficient of skewness of the distribution of the accession values, and the standard error of the difference between accession values $\left(\mathrm{S}_{\mathrm{D}}\right)$. ACC Number, see Table 1 for accession details

\begin{tabular}{|c|c|c|c|c|c|}
\hline Trait & Minimum & Maximum & $\sigma$ & Skewness & $\mathrm{S}_{\mathrm{D}}$ \\
\hline \multicolumn{6}{|c|}{ Phenology } \\
\hline Flowering (days) & ACC 35, ACC 38, ACC 39 & ACC 1 & 11.6 & -0.07 & $1.95 * * *$ \\
\hline Growth cycle (days) & ACC 15, ACC 34, ACC 54 & ACC 1, ACC 13, ACC 45 & 12.0 & 0.60 & $2.9^{* * *}$ \\
\hline \multicolumn{6}{|c|}{ Pod and seed traits } \\
\hline Seed size $(\mathrm{g} / 100$ seed $)$ & ACC 45, ACC 74, ACC 93 & ACC 15, ACC 76, ACC 81 & 0.41 & 1.05 & $0.12 * * *$ \\
\hline Seeds per pod & ACC 23, ACC 56, ACC 57 & ACC 2, ACC 30, ACC 88 & 1.06 & 0.35 & $0.67 * * *$ \\
\hline Pod length (mm) & ACC 56, ACC 68, ACC 74 & ACC 15, ACC 20, ACC 110 & 6.4 & -0.17 & $3.60 * *$ \\
\hline Seed protein $(\% \mathrm{w} / \mathrm{w})$ & ACC 16, ACC 21, ACC106 & ACC 29, ACC 36, ACC 41 & 1.45 & -0.13 & $0.83^{*}$ \\
\hline Hardseededness (\%) & ACC 81 & Most accessions & 10.6 & -2.93 & $8.3 * * *$ \\
\hline \multicolumn{6}{|c|}{ Morphological traits } \\
\hline Seedling height $(\mathrm{mm})$ & ACC 59, ACC 72 & ACC 110 & 6.0 & 0.65 & $4.7 * * *$ \\
\hline Primary leaf size \& shape Length (mm) & ACC 42, ACC 44, ACC 64 & ACC 61, ACC 81, ACC 105 & 3.6 & 0.10 & $3.7 * * *$ \\
\hline Breadth $(\mathrm{mm})$ & ACC 31, ACC 66, ACC 74 & ACC 20, ACC 21, ACC 76 & 2.8 & 0.55 & $3.7 *$ \\
\hline Length to breadth ratio & ACC 20, ACC 39, ACC 76 & ACC 66, ACC 68 & 0.88 & 1.32 & $0.60 * * *$ \\
\hline Leaf lobing score $(0-5)$ & ACC 55, ACC 74, ACC 101 & ACC 38, ACC 80, ACC 113 & 0.98 & 0.06 & $0.32 * * *$ \\
\hline Stem diam. above 4 th trifolioliate $(\mathrm{mm})$ & ACC 55, ACC 63, ACC 74 & ACC 75, ACC 76, ACC 113 & 0.58 & 0.01 & $0.94 * * *$ \\
\hline Stipule breadth $(\mathrm{mm})$ & ACC 32, ACC 36, ACC 111 & ACC 42, ACC 82, ACC 83 & 0.73 & 0.77 & $0.33^{* * *}$ \\
\hline Width of floral standard (mm) & ACC 7, ACC 19, ACC 37 & ACC 83, ACC 90, ACC 91 & 1.8 & -1.25 & $1.70 * * *$ \\
\hline Habit score $(1-4)$ & ACC 44, ACC 81 & ACC 3, ACC 41, ACC 83 & 0.26 & -0.35 & $0.39 * * *$ \\
\hline \multicolumn{6}{|c|}{ Biomass and seed yield } \\
\hline Total dry matter $\left(\mathrm{g} / \mathrm{m}^{2}\right)$ & ACC 34, ACC 44, ACC 74 & ACC 11, ACC 23, ACC 114 & 53 & 0.20 & $26.3 * * *$ \\
\hline Seed yield $\left(\mathrm{g} / \mathrm{m}^{2}\right)$ & ACC 29, ACC 44, ACC 71 & ACC 35, ACC 38, ACC 54 & 16.9 & 1.81 & $7.6^{* * *}$ \\
\hline Harvest index & ACC 27, ACC 44, ACC 87 & ACC 35, ACC 38, ACC 54 & 0.05 & 1.24 & $0.015^{* * *}$ \\
\hline \multicolumn{6}{|c|}{ Disease reaction $(0-3)$} \\
\hline Cercospora leaf spot rating & ACC 28, ACC 47, ACC 66 & ACC 24, ACC 34, ACC 97 & 0.52 & 0.92 & $0.27 * * *$ \\
\hline Powdery mildew rating & ACC 1, ACC 28, ACC 66 & ACC 38, ACC 94 & 0.4 & 1.94 & $0.27 * * *$ \\
\hline Halo blight rating & ACC 1, ACC 47, ACC 89 & ACC 50, ACC 93, ACC 97 & 0.4 & 0.90 & $0.35 * * *$ \\
\hline
\end{tabular}

$* P \leq 0.05 ; * * P \leq 0.01 ; * * * P \leq 0.001$.

was due to later flowering in the wild types. Many of the wild types also flowered and set pods over an extended period relative to the cultivar. The range in phenology of the Indian accessions was generally narrower than, and within that of the Austronesian accessions, perhaps reflecting the smaller sample of accessions evaluated.

Within the Austronesian accessions (Table 3), the earliest flowering lines came from the Central Highlands in Queensland (cf. Table 1). The latest flowering accession, ACC 1, from near Mackay, was more than 10 days later than all other accessions and was uniquely late flowering (>98 days) in all 4 environments. Two of the 3 shortest duration lines came from inland NW Australia, whereas the 3 longest duration lines were coastal accessions from NE Queensland and Papua New Guinea. The frequency distributions for time to flowering (Fig. 1a) and duration (Fig. 1b) were near normal.

\section{Pod and seed traits}

There were considerable differences in seed size between the groups and within the wild accessions (Table 2).
The average seed size for the Austronesian accessions was only about $20 \%$ that of the cultivar. The average seed size for the Indian accessions was about twice that of the Austronesian group and the upper end of the range for the Indian accessions extended beyond that of the Austronesian group. Even so, the largest seeded Indian type was still only at the lower end of the range for cultivated mungbean (c. $3 \mathrm{~g} / 100 \mathrm{seeds}$ ). At the other end of the scale, the smallest seeded Austronesian accessions were only about $10 \%$ of the large seed size (c. $7 \mathrm{~g} / 100$ seeds) sometimes preferred for sprouting.

The differences between groups in the numbers of seeds per pod and pod length were relatively smaller than those in seed size. Again, the wild types tended to be smaller than the cultivar, with the Indian accessions clustered towards the upper end of the range for the wild types. The range in numbers of seeds per pod among the Austronesian accessions was relatively wide, encompassing that of the other 2 groups. The 3 Austronesian lines with the most seeds per pod (Table 3) came from NE Queensland (Table 1) and have been subsequently found to be perennial. The 3 lines with 

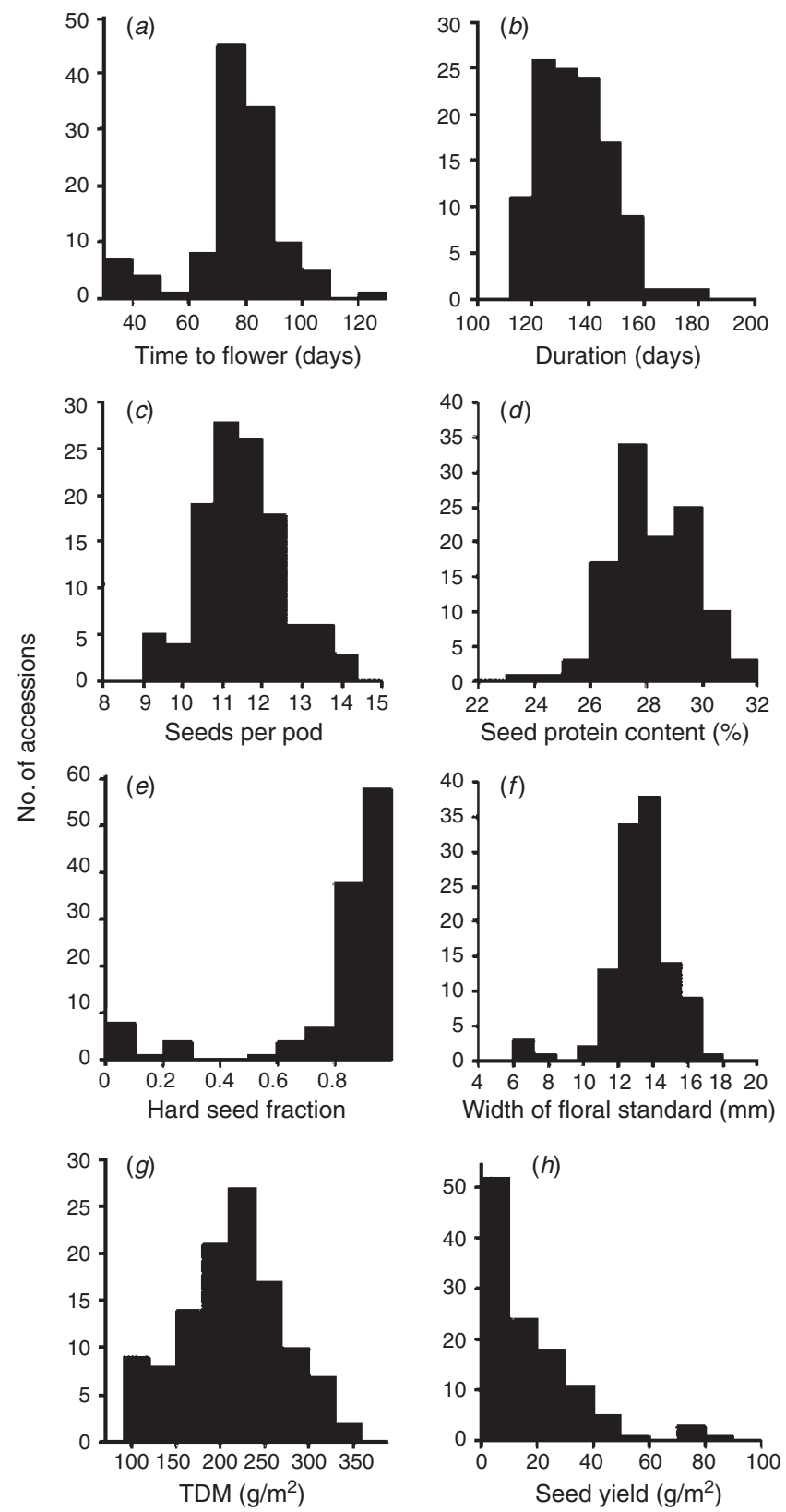

Fig. 1. Frequency distributions for selected traits among ssp. sublobata accessions from Australia and nearby islands.

the fewest seeds per pod all came from around Mackay in central Queensland. The distribution of seeds per pod was near normal (Fig. 1c).

Differences in the average seed protein content between groups were small albeit significant (Table 2). Potentially of more agronomic interest, there was a wide range in protein content of the Austronesian accessions, with about half the accessions matching or exceeding the protein level of the cultivar. Indeed, the protein content of many of the Austronesian accessions exceeded that of a wide range of mungbean germplasm examined by Imrie et al. (1981a). The distribution of seed protein content was near normal (Fig. 1d).

Differences between the groups in the levels of hard seed were large (Table 2). The Austronesian accessions had high average levels of hard seed, the Indian accessions were intermediate, and the cultivar was soft seeded. Within the Austronesian group, the distribution for hardseededness was strongly skewed, with most lines having $>95 \%$ hard seed (Table 3, Fig. 1e). ACC 81, a relatively large seeded line from West Timor, was the only Austronesian line with $<50 \%$ hard seed. Interestingly, ACC 81 comprised a mix of seed colours including green (Table 1), which may reflect past outcrossing with cultivated mungbean (see below). ACC 76, from the Northern Territory, combined the lowest level of hard seed $(56 \%)$ with the largest seed size of the mainland accessions.

\section{Plant morphological traits}

There were large differences between and within groups in seedling height, and the length and width of the primary leaves (Table 2), which appeared to broadly reflect those in seed size. Again, the Indian accessions tended to fall at, and extend beyond, the upper end of the range in size of the Austronesian accessions, but were nonetheless smaller than the cultivar.

On average, the shape of the primary leaf, as indicated by the length to width ratio, was similar in all 3 germplasm groups (Table 2). However, the range in the shape of the primary leaf was large in the Austronesian accessions (Table 3). Two of the 3 accessions with the most ovate primary leaves came from NW Australia, whereas the 2 lines with the most lanceolate leaves came from West Timor. The distribution of primary leaf shape was skewed towards ovate leaves, with relatively few narrow or lanceolate-leaved forms.

The differences between and within groups in the size and shape of mature terminal leaflets broadly mirrored those in the seedling leaves (Table 2). Again, the leaflets of the Austronesian accessions were on average smaller than in the Indian accessions, which in turn were much smaller than the cultivar. There was substantial overlap, however, between accessions in the 2 ssp. sublobata groups. The Austronesian accessions generally had narrower leaves than the other 2 groups, although again, there was a wide range in leaf shape with a few accessions with leaves as broad as long.

Leaflet lobing, the attribute responsible for the subspecies epithet, was generally more pronounced in the Austronesian than in the Indian accessions of ssp. sublobata. As with other traits, however, there was a wide range in expression of leaflet lobing in the Austronesian accessions, ranging from complete absence of lobing to deeply scalloped leaves (Table 3). Strongly lobed accessions were collected from throughout the 
geographical range. However, lobing was especially evident in accessions adapted to the cracking clay soils from the brigalow belt in central Queensland. Whereas cv. Satin has no lobing, lobed cultivars of mungbean are grown in some parts of India and Asia.

There were clear differences in stem diameter between the Austronesian accessions and the other 2 groups (Table 2), with the Austronesian accessions invariably finer-stemmed than either the Indian accessions or cv. Satin. Meanwhile, some of the Indian accessions were broader stemmed than the cultivar. There were differences among accessions in both ssp. sublobata groups in the presence or absence of anthocyanin in the stem, and in levels of expression, above and below the cotyledonary node. The expression of anthocyanin in the seedling stem is sometimes viewed as an undesirable trait in mungbean sprouts and is considered by industry as a weakness in cv. Satin.

There was a wide range of stipule length, breadth, and thickness among the wild accessions (Table 2). In general, the wild type stipules tended to be smaller and narrower than in the cultivar, and were generally larger and broader in the Indian accessions than in the Austronesian accessions. The latter, nonetheless, showed a very broad range, with some extending beyond the cultivar in size and shape.

There was likewise a very broad range in the size of the floral standard within the Austronesian accessions (Table 2, Fig. $1 f$ ). Although, on average, the flowers in this group were smaller than in the Indian accessions and the cultivar, the range extended from flowers only half the size of the cultivar to flowers $20 \%$ larger. All 3 lines with the widest standards came from the Townsville-Charters Towers region in northern Queensland (Table 3).

There were clear differences between the groups in plant habit and the presence or absence of stem twining (Table 2). Whereas the Austronesian accessions were all prostrate or at best semi-erect twining vines, the Indian accessions were suberect and tended to trail rather than twine.

Several accessions were also observed to exhibit the perennial habit through root tuberisation reported by Lawn and Cottrell (1988). Eight accessions (ACC 3, ACC 25, ACC 26, ACC 87, ACC 89, ACC 90, ACC 91, and ACC 92) regenerated shoots from tuberous roots in one or both replicate plots in the first sowing at Samford. All of these accessions were obtained from a small region centred on Townsville-Charters Towers (Table 1). The area is predominately seasonally arid, tropical savannah grassland dominated by spear grass (Heteropogon contortus). In addition, several accessions from nearby areas had thickened, tuberised roots that may have allowed regeneration in more favourable (tropical) conditions.

In terms of gross vegetative morphology, the perennial accessions appeared generally similar to the annual accessions, apart from the development of thickened tap and lateral roots quite unlike the normal fibrous root system of the annual accessions and of mungbean. As with the annual accessions, vegetative growth in the perennial accessions ceased with the onset of cooler temperatures in winter, but with warmer spring temperatures, commenced again from adventitious shoots on the thickened tap and lateral roots.

At least $20 \%$ of the prostrate Austronesian accessions developed roots at nodes in contact with moist soil in the first sowing in the subtropics (data not shown). Nodal roots were often fine but still penetrated the soil to some depth.

\section{Biomass and seed yield}

The differences in total dry biomass production (TDM) among the 3 groups were substantial (Table 2). The average biomass of the Austronesian accessions was only two-thirds that of the Indian accessions, which in turn was about half that of Satin. It is likely that the TDM of the wild accessions was underestimated to the extent that fallen senescent leaves were not recovered during growth, resulting in a bias that was inevitably greater in the later maturing lines.

Group differences in seed yield were relatively larger than those in TDM, especially between the 2 ssp. sublobata groups, which on average yielded much less seed than cv. Satin. Although, on average, slightly higher yielding than the Austronesian ssp. sublobata accessions, the Indian accessions nonetheless all fell within the range of the Austronesian accessions.

The range in biomass production among accessions within the 2 wild groups was in relative terms much less than that in seed yield. Although the wild accessions were generally vegetatively vigorous, some of the late flowering Austronesian accessions produced only traces of seed, resulting in very low HI. Thus the mean $\mathrm{HI}$ of the Indian wild accessions was on average greater than for the Austronesian group. Even so, the HI of all the wild accessions in both groups was substantially less than in the cultivar, and as with seed yield, the HI of none of the Indian accessions was outside of the range of the Austronesian accessions. Had senescent leaf been recovered, the $\mathrm{HI}$ of the wild lines would have been even lower.

Within the Austronesian accessions, biomass production was normally distributed (Fig. 1g), whereas seed yield (Fig. 1h) and HI were highly skewed to the lower end of the range, with only a few lines having high yield and/or high HI. The 3 accessions with highest HI also had highest yield (Table 3). Two of these came from the Queensland Central Highlands.

The low seed yields and $\mathrm{HI}$ of the wild accessions reflected the general trends identified in many other species, namely, that seed yield improvements through domestication have come less through increases in biomass than though improvements in HI (Evans and Dunstone 1970; Donald and Hamblin 1984; Lawn 1989a). 


\section{Disease reaction}

On average, the severity of infection with all 3 leaf diseases was greater in the Austronesian wild accessions than in cv. Satin, which in turn was more affected than the Indian wild accessions (Table 2). Although there are various possible explanations for the apparently better average performance of the Indian wild accessions, Indian mungbean varieties are generally regarded as having superior levels of resistance to a range of diseases relative to east Asian mungbean varieties (Imrie et al. 1981b).

Of most potential significance, there were some accessions in both of the ssp. sublobata groups that exhibited no disease symptoms whatsoever. For example, within the Austronesian group (Table 3), there were 5 accessions (ACC 1, ACC 28, ACC 47, ACC 66, ACC 89) that had zero or negligible infection of all 3 diseases.

Given the opportunistic nature of the collection of the disease ratings, and the fact that no systematic attempt was made to inoculate the plots (indeed, spraying was done to minimise the damage caused by disease), these data need to be interpreted with caution. For example, it is possible that some of the observed differences were due to chance differences in disease inoculum pressure.

Nonetheless, the incidence of all 3 diseases was widespread within the plots, with many instances of disease-free plots located adjacent to severely infected plots. As such, it is likely that at least some of the observed differences reflect underlying genotypic differences in disease susceptibility that may prove useful in breeding disease-resistant mungbean cultivars. For example, similar opportunistic observations identified major gene resistance to bruchid seed weevil damage in an accession of ssp. sublobata collected at Somerset Dam west of Brisbane (James et al. $1999)$, and to powdery mildew infection in $V$. vexillata (James and Lawn 1991).

\section{Environmental effects on selected traits}

The expression of differences between accessions for a range of morphological traits, such as size and shape of seedling and mature leaflets, stipules, and the floral standard, leaflet lobing, the presence and extent of anthocyanin pigmentation, and plant habit and twining, was largely independent of the environment. However, for phenology, biomass, and seed yield, and for seed and pod traits except hardseededness, there were large environmental effects $(P \leq 0.01)$ that usually exceeded in magnitude those due to accessions $(\mathrm{G})$, and accession $\times$ environment $(\mathrm{G} \times \mathrm{E})$ interaction (data not shown). Nonetheless, again with the exception of hardseededness, there were highly significant $(P \leq 0.001) \mathrm{G}$ and $\mathrm{G} \times \mathrm{E}$ effects for these traits (Table 4$)$.

For all the phenological phases, but particularly the durations of the reproductive phase and total growth, the $\mathrm{G} \times \mathrm{E}$ effects were of comparable or greater magnitude than those due to $G$ alone (Table 4), confirming the necessity of multi-environment testing for the meaningful discrimination among accessions in relation to phenology. Broad-sense heritability $\left(\mathrm{h}^{2} \mathrm{~b}\right)$ was generally high, and the relative magnitudes of the interaction effect were consistent with those reported for cultivated mungbean (Imrie and Butler 1982).

Table 4. Relative magnitudes of accession (G) and accession $x$ environment $(G \times E)$ effects, broadsense heritability $\left(h^{2}\right)$, and accession coefficient of variation (GCV\%), for selected traits for a subset of 108 ssp. sublobata accessions from Australia and nearby islands, when grown at an early and a late sowing, at a tropical and a subtropical site

\begin{tabular}{|c|c|c|c|c|}
\hline \multirow[t]{2}{*}{ Trait } & \multicolumn{2}{|c|}{ Variance components \pm standard error } & \multirow[t]{2}{*}{$\mathrm{h}^{2}{ }_{\mathrm{b}}$} & \multirow[t]{2}{*}{$\mathrm{GCV} \%$} \\
\hline & $\mathrm{G}$ & $\mathrm{G} \times \mathrm{E}$ & & \\
\hline \multicolumn{5}{|c|}{ Phenology } \\
\hline Emergence (days) & $0.07 \pm 0.01 * * *$ & $0.10 \pm 0.01 * *$ & 0.80 & 5.3 \\
\hline First flower (days) & $112.8 \pm 17.3 * * *$ & $86.3 \pm 8.0^{* * *}$ & 0.97 & 13.1 \\
\hline Reproductive growth (days) & $78.9 \pm 18.3 * * *$ & $225.4 \pm 21.4^{* * *}$ & 0.82 & 14.6 \\
\hline Maturity (days) & $131.3 \pm 19.6^{* * *}$ & $295.0 \pm 26.4^{* * *}$ & 0.95 & 8.2 \\
\hline \multicolumn{5}{|c|}{ Pod and seed traits } \\
\hline Seed size (g/100 seed) & $0.102 \pm 0.004 * * *$ & $0.001 \pm 0.002 * * *$ & 0.96 & 23.9 \\
\hline Seeds per pod & $0.61 \pm 0.11^{* * *}$ & $0.27 \pm 0.05^{* * *}$ & 0.94 & 6.7 \\
\hline Pod length (mm) & $24.4 \pm 3.8^{* * *}$ & $4.4 \pm 0.7 * * *$ & 0.93 & 9.1 \\
\hline Seed protein $(\% \mathrm{w} / \mathrm{w})$ & $0.6 \pm 0.1 * * *$ & $1.8 \pm 0.8 * * *$ & 0.45 & 2.7 \\
\hline Hardseededness (\%) & $0.008 \pm 0.002 * *$ & n.s. & 0.60 & 10.1 \\
\hline \multicolumn{5}{|c|}{ Biomass and seed yield } \\
\hline Total dry matter $\left(\mathrm{g} / \mathrm{m}^{2}\right)$ & $2100 \pm 510^{* * *}$ & $3200 \pm 500^{* * *}$ & 0.59 & 20.6 \\
\hline Seed yield $\left(\mathrm{g} / \mathrm{m}^{2}\right)$ & $203.5 \pm 51.6^{* * *}$ & $250.0 \pm 34.9 * * *$ & 0.64 & 77.7 \\
\hline Harvest index & $0.002 \pm 0.0003 * * *$ & $0.001 \pm 0.0002 * * *$ & 0.82 & 56.3 \\
\hline
\end{tabular}

n.s., Not significant $(P>0.05) ; * * P \leq 0.01 ; * * * P \leq 0.001$. 
Among phenology traits, accession coefficients of variation $(\mathrm{GCV} \%)$ were smaller for time to emergence and total growth duration than for time to flower and the duration of reproductive growth. Observation suggested that in large part, the differences in the duration of the reproductive growth phase reflected differences in the extent to which successive flushes of flowering and podding occurred. As discussed below, there was evidence that differential genotypic photoperiodic responses contributed substantially to the observed differences in phenology among accessions, sowing dates, and environments.

In contrast to phenology, the magnitude of $G$ effects was much greater than $\mathrm{G} \times \mathrm{E}$ for most pod and seed traits (Table 4), indicating that the expression of these traits was more stable over the 4 environments. The clear exception was seed protein content, where the magnitude of the $\mathrm{G} \times \mathrm{E}$ effect was substantially greater than that due to G. In general, the smaller contribution of $\mathrm{G} \times \mathrm{E}$ effects to the observed variability of the pod and seed traits reflected responses observed in mungbean (Fernandez and Chen 1989). Not surprisingly, broad-sense heritability was moderate to high for most seed traits except seed protein content. The magnitudes of the GCV\% indicated that seed size was the most variable of the pod and seed traits, and seed protein content the least, among the accessions.

For seed yield and TDM, the magnitude of $\mathrm{G} \times \mathrm{E}$ effects was relatively greater than the $G$ variance component, indicating large differential responses over environment (Table 4). In contrast, HI was more stable over environments, so that its broad-sense heritability was greater than that for either seed yield or biomass. The GCV\% estimates for the respective traits supported the indications in Tables 2 and 3 that the variation in biomass among accessions was less than that in seed yield and HI.

\section{Interrelations between traits}

Across the population of ssp. sublobata accessions, there was a large number of correlations among traits, some of which appeared to have plausible physiological or adaptive explanation. For example, growth cycle duration (days) was positively correlated $\left(r=0.69^{* *}\right)$ to time to flower. However, although later flowering accessions were later maturing, there was a trend for a compensatory shortening of the reproductive phase, so that there was a negative correlation $\left(r=-0.36^{* *}\right)$ between time to flower and the length of the post-flowering phase.

Pod length was positively correlated to both the number of seeds per pod $\left(r=0.50^{* *}\right)$ and to seed size $\left(r=0.70^{* *}\right)$. There was a negative correlation $\left(r=-0.61^{* *}\right)$ between seed size and seed hardness. Recent research involving ssp. sublobata $\times$ ssp. radiata hybrids has identified several quantitative trait loci contributing to that correlation (Humphry et al. 2005). Seed protein content was also negatively correlated to seed size $(r=-0.24 *)$, although the correlation was not sufficiently strong to preclude the possibility that genotypes combining larger seed and higher protein content might be developed through genetic recombination and selection. There were small but positive correlations between the duration of the reproductive (postflowering) phase and seed protein content $\left(r=0.27^{* *}\right)$, seeds per pod $\left(r=0.29^{* *}\right)$, and seed yield $\left(r=0.34^{* *}\right)$.

Among accessions, there was a general trend for 'wild type' morphological traits to be associated. For example, prostrate habit was positively correlated to twining $\left(r=0.80^{* *}\right)$, anthocyanin intensity in the stem $\left(r=0.47^{* *}\right)$, and hardseededness $(r=0.72 * *)$, and negatively to stem diameter $\left(r=-0.70^{* *}\right)$, leaflet length $\left(r=-0.44^{* *}\right)$, and seed size $\left(r=-0.64^{* *}\right)$.

Among accessions, seed yield was positively correlated to both its components, total biomass production $\left(r=0.44^{* *}\right)$ and HI $\left(r=0.93^{* *}\right)$. The relatively stronger correlation to HI may reflect the fact that vegetative growth was generally vigorous, with closed canopies forming early in growth. Seed yield was negatively correlated $(r=-0.72 * *)$ to the time to flower, largely because the later flowering lines had lower HI $\left(r=-0.73^{* *}\right)$. Similar negative correlations between time to flowering and HI have been widely observed in cultivated grain legumes including mungbean (Lawn 1989a).

There were no apparent correlations between any of the disease severity ratings and the geographical attributes of provenance. There were small but consistent negative correlations between accession duration and disease rating, for cercospora $\left(r=-0.47^{* *}\right)$, powdery mildew $\left(r=-0.44^{* *}\right)$, and halo blight $\left(r=-0.31^{* *}\right)$. These correlations may suggest that the later accessions 'escaped' more serious infection because they were at an earlier stage of ontogeny when the disease outbreaks occurred, although the correlations between disease severity and time to flowering were smaller than with duration. The severity of cercospora infection was correlated to the severity of halo blight infection $\left(r=0.55^{* *}\right)$ and to the severity of powdery mildew rating $\left(r=0.28^{* *}\right)$, but there was no correlation between halo blight and powdery mildew infection. These correlations may reflect the existence of multiple resistances in some accessions or, alternatively, indicate that prior infection by one disease organism increased susceptibility to infection by others.

The severity of halo blight infection was fairly strongly correlated $\left(r=0.79^{* *}\right)$ to the severity of a transient seedling chlorosis, believed to have been caused by zinc deficiency following short-term waterlogging (Rebetzke 1994). Again, the reaction may reflect a pre-disposition to disease infection in weakened plants. Other attributes that were correlated with disease severity included stipule breadth, which was weakly negatively correlated to severity of all 3 diseases, and intensity of anthocyanin pigmentation in the stem, which was weakly negatively correlated $\left(r=-0.27^{* *}\right)$ to powdery mildew infection. 
Among the few distinguishing morphological features of the perennial accessions other than the presence of tuberous roots was a tendency for a wider floral standard $\left(r=0.47^{* *}\right)$, a broader stipule $\left(r=0.43^{* *}\right)$, and more seeds per pod $\left(r=0.36^{* *}\right)$.

\section{Variation in traits with provenance}

Among accessions, the mean days to flowering (f) across environments was negatively correlated $\left(r=-0.29^{* *}\right)$ with latitude of origin. Similar correlations have been found for cultivated Vigna species including mungbean (e.g. Lawn 1979) and for the endemic wild species $V$. lanceolata (Lawn and Holland 2003). The response is consistent with quantitative short-day photoperiodic adaptation.

Because day length varies systematically with latitude, a negative association is to be expected between time to flowering and latitude of origin for any diverse set of shortday photoperiod-sensitive accessions when grown at the one location (Roberts and Summerfield 1987). Accessions adapted to the tropics normally flower under much shorter days in the summer than those experienced at subtropical latitudes, so that flowering tends to be delayed when tropical lines are cultivated in the subtropics. Conversely, accessions adapted to the subtropics flower quickly when cultivated in the shorter days of the tropics. In both tropical and subtropical environments, most lines are stimulated to flower rapidly when sown late in the summer, because days are shortening regardless of latitude.

In physiological terms, the rate of development towards flowering (approximated by $1 / \mathrm{f}$ ) tends, in short-day plants, to be faster in lines that are adapted to higher latitudes, and slowest for those adapted to the tropics. Consistent with this interpretation, there were positive correlations among accessions between $1 / \mathrm{f}$ and latitude of origin for the first sowing in both the tropics $\left(r=0.44^{* *}\right)$ and the subtropics $\left(r=0.42^{* *}\right)$. However, in the later sowings, where day lengths were relatively short, the correlations were small and non-significant.

As expected, there was a positive correlation $\left(r=0.79^{* *}\right)$ between the accession means for $1 / \mathrm{f}$ in the first sowings in the tropics and the subtropics, with $1 / \mathrm{f}$ invariably larger in the tropics. Likewise, there was a negative correlation $\left(r=-0.45^{* *}\right)$ between the difference in $1 / \mathrm{f}$ for locations and the latitude of origin. That is, when sown in the subtropics, the rate of development towards flowering was slowed more in the accessions from lower latitudes than in those from the subtropics.

Interestingly, the difference in time to flowering between the first sowing in the tropics and that in the subtropics was negatively correlated $\left(r=-0.31^{* *}\right)$ to altitude of collection. This suggested that flowering tended to be less affected by longer days in those accessions collected at higher altitude. In part, this may reflect an adaptive response, in that the higher altitude collection sites were usually inland, where the duration of the growth period in terms of favourable temperatures and rainfall tends to be shorter than in lower latitude coastal areas. Accessions of the endemic species $V$. lanceolata from inland areas flowered sooner than coastal accessions from the same latitude (Lawn and Holland 2003).

Among accessions, there were negative correlations between the longitude of collection location and attributes of size such as leaflet length $\left(r=-0.41^{* *}\right)$, stem diameter $\left(r=-0.56^{* *}\right)$, pod length $\left(r=-0.31^{* *}\right)$, and seed size $\left(r=-0.53^{* *}\right)$. That is, the more easterly occurring accessions tended to be less robust in form. These relationships with longitude corroborate the broad group differences identified in Table 2, and imply that accessions occurring further away from the putative centre of domestication of mungbean in the Indo-Burmese region are more finestemmed and gracile. Consistent with this interpretation, analogous correlations were apparent among the accessions between these traits and their latitudinal dispersion south. For example, among accessions, latitudinal dispersion south was negatively correlated to stem diameter $\left(r=-0.60^{* *}\right)$, leaflet length $\left(r=-0.39^{* *}\right)$, stipule length $\left(r=-0.31^{* *}\right)$, seedling height $\left(r=-0.52^{* *}\right)$, and seed size $\left(r=-0.42^{* *}\right)$.

There were also negative correlations between altitude of collection site, and wild type characters such as prostrate habit $\left(r=-0.27^{* *}\right)$, hardseededness $\left(r=-0.30^{* *}\right)$, twining $\left(r=-0.35^{* *}\right)$, and seed size $\left(r=-0.28^{* *}\right)$. In part, these trends reflected the fact that all of the more robust Indian collections were made at altitude, whereas the most gracile of the Australian collections, i.e. those from the eastern subtropics, were invariably restricted to the coast.

These general geographic trends may reflect differing levels of introgression between the wild plants and cultivated mungbean throughout the range from which the accessions were collected. Domestication favours traits such as erect habit, robust form, large seed size, and soft-seededness, that are unfit in terms of long-term survival in the wild (Smartt 1978; Donald and Hamblin 1984). Whereas the widespread cultivation of mungbean throughout much of the range of the wild species, including in West Timor, would have provided opportunity for introgressive exchange between the wild species and cultivated mungbean, there has been minimal such opportunity in the more easterly and southerly parts of its range in Australia.

Certainly, among accessions, dispersion south was positively correlated to putative 'wild type' traits such as twining $\left(r=0.86^{* *}\right)$, prostrate habit $\left(r=0.79^{* *}\right)$, leaf lobing score $\left(r=0.36^{* *}\right)$, hardseededness $\left(r=0.67^{* *}\right)$, and anthocyanin intensity in the stem. Similar trends in wild type traits were evident with longitude of collection location, which was positively correlated to prostrate habit $\left(r=0.72^{* *}\right)$, hardseededness $\left(r=0.56^{* *}\right)$, and twining $\left(r=0.69^{* *}\right)$. The more easterly accessions also tended to have higher seed protein content $\left(r=0.36^{* *}\right)$. 
If this interpretation is correct, it is likely that the expansion of commercial mungbean production in locations throughout the natural range of ssp. sublobata in northern Australia will see the progressive introgression of traits of domestication into the indigenous wild germplasm. In time, it is possible that weedy forms analogous to those collected in India will also develop in Australia.

\section{Conclusions}

Based on a comparison with a subset of Indian accessions and a cultivar, there is a wide range of variation for traits of potential agronomic, adaptive, or taxonomic interest among the accessions of wild mungbean indigenous to Australia and nearby islands. In some instances, e.g. phenology, seeds per pod, seed protein content, and seed hardness, the range of variation among the Austronesian lines was greater than that observed in the Indian and in cultivated lines.

The variation among wild mungbean accessions for some of the traits appeared to be systematic, with plausible underlying physiological or adaptive explanations. For example, the variation in phenology with latitude of provenance was consistent with quantitative short-day photoperiodic adaptation. There was also a tendency for wildtype traits, such as prostrate habit, more gracile morphology, twining form, and small and hard seed, to be associated.

In general terms, there was little evidence of typical 'traits of domestication' in the Australian accessions apart from one shiny seeded segregate (ACC $87 \mathrm{~S}$ ), which was likely a chance mutation. In contrast, the offshore lines included occasional green seeded types. Indeed, there was a general geographic trend whereby lines collected from locations more remote from those regions in southern and eastern Asia where mungbean has traditionally been cultivated showed greater expression of wild-type traits. This geographic trend was broadly consistent with the conclusions of Saravanakumar et al. (2004), who grouped ssp. sublobata accessions on the basis of a similarity coefficient based on molecular markers, in the order Myanmar - India - Madagascar - Indonesia Australia/Papua New Guinea.

There was some unique variation among the Australian accessions, most notably the tuberous rooting and perennial habit of accessions collected from the TownsvilleCharters Towers region. Some of the identified variation, e.g. higher protein content, hardseededness, and putative disease resistance, may be of value in mungbean varietal improvement.

It is probable that a more systematic and targetted evaluation of the collection than that undertaken here would reveal additional adaptations. For example, there is qualitative evidence that lines collected from degraded saline areas in West Timor are better adapted to saline conditions, whereas lines from the brigalow belt in central Queensland are well adapted to cracking clay soils (Lawn and Watkinson 2002).
From a plant-breeding perspective, the transfer of genes from the wild accessions into mungbean varieties is likely to be relatively straightforward. The Australian forms of ssp. sublobata hybridise readily with cultivated mungbean, with apparently normal inheritance for a range of qualitative and quantitative traits (James et al. 1999). As such, the wild accessions are a potentially valuable germplasm resource.

Given their vegetative vigour, the wild accessions might also be potentially useful in their own right as a forage crop, especially if the tuberous rooting character could be developed to enhance persistence under cutting or grazing.

\section{Acknowledgments}

The research reported here was supported by the Grains Research and Development Corporation and the CSIRO Division of Tropical Crops and Pastures. The collection of the data at Lansdown by Dr Patricia Chay-Prove and Mr Doug Horan, and the assistance of Mr Andrew Watkinson at Samford, are acknowledged with appreciation. The paper includes research undertaken by GJR in partial fulfillment of the requirements of the MAgrSc degree at the University of Queensland.

\section{References}

Cook SJ, Russell JS (1983) The climate of seven CSIRO field stations in northern Australia. Technical Paper No. 25, CSIRO Division of Tropical Crops and Pastures, Brisbane, Qld.

Donald CM, Hamblin J (1984) The convergent evolution of annual seed crops in agriculture. Advances in Agronomy 36, 97-143.

Evans LT, Dunstone RL (1970) Some physiological aspects of evolution in wheat. Australian Journal of Biological Sciences 23, 725-741.

Fernandez GCJ, Chen HK (1989) Implications of year $\times$ season $\times$ genotype interactions in mungbean yield trials. Journal of the American Society for Horticultural Science 114, 999-1002.

Grant T, Lawn RJ, Bielig LM (2003) Variation among Australian accessions of Vigna vexillata for traits of agronomic, adaptive or taxonomic interest. Australian Journal of Agricultural Research 54, 243-250. doi: 10.1071/AR02147

Hallauer AR, Miranda JB (1988) 'Quantitative genetics in maize breeding.' (Iowa State University Press: Ames, IA)

Humphry ME, Lambrides CJ, Chapman SC, Aitken EAB, Imrie BC, Lawn RJ, McIntyre CL, Liu CJ (2005) Relationships between hard-seededness and seed weight in mungbean (Vigna radiata) assessed by QTL analysis. Plant Breeding 124, 292-298. doi: 10.1111/j.1439-0523.2005.01084.x

Imrie BC, Beech DF, Blogg D, Thomas B (1981a) Mungbean catalogue. Genetic Resources Communication No. 2, CSIRO Division of Tropical Crops and Pastures, Brisbane, Qld.

Imrie BC, Butler KL (1982) An analysis of the variability and genotype $\times$ environment interaction in mungbean (Vigna radiata) in south-eastern Queensland. Australian Journal of Agricultural Research 33, 523-530. doi: 10.1071/AR9820523

Imrie BC, Drake DW, De Lacy IH, Byth DE (1981b) Analysis of genotypic and environmental variation in international mungbean trials. Euphytica 30, 301-311. doi: 10.1007/BF00033991 
James AT, Lawn RJ, Williams RW, Lambrides CJ (1999) Cross fertility of Australian accessions of wild mungbean (Vigna radiata ssp. sublobata) with green gram ( $V$. radiata ssp. radiata) and black gram (V. mungo). Australian Journal of Botany 47, 601-610. doi: 10.1071/BT97068

James AT, Lawn RJ (1991) Inheritance of selected traits in accessions of Vigna vexillata (L.) A. Rich of Australian and African origin. Australian Journal of Botany 39, 415-429. doi: 10.1071/BT9910415

Johnson AD, Simons JG, Hansen RW, Daniel RA (1985) Chemical procedures for the analysis of plant material: multielement, oil, sugars and gums. Technical memorandum 40, CSIRO Division of Tropical Crops and Pastures, Brisbane, Qld.

Lambrides CJ, Imrie BC (2000) Susceptibility of mungbean varieties to the bruchid species Callosobruchus maculatus (F.), C. phaseoli (Gyll.), C. chinensis (L.), and Acanthoscelides obtectus (Say.) (Coleoptera: Chrysomelidae). Australian Journal of Agricultural Research 51, 85-89. doi: 10.1071/AR99051

Lambrides CJ, Lawn RJ, Godwin ID, Manners J, Imrie BC (2000) Two genetic linkage maps of mungbean using RFLP and RAPD markers. Australian Journal of Agricultural Research 51, 415-425. doi: 10.1071/AR99052

Lawn RJ (1979) Agronomic studies on Vigna spp. in south-eastern Queensland I. Phenological response of cultivars to sowing date. Australian Journal of Agricultural Research 30, 855-870. doi: 10.1071/AR9790855

Lawn RJ (1989a) Agronomic and physiological constraints to productivity of tropical grain legumes and prospects for improvement. Experimental Agriculture 25, 509-528.

Lawn RJ (1989b) Registration of Australian grain legume cultivars: Vigna radiata (Mungbean) cv. Satin. Australian Journal of Experimental Agriculture 29, 918. doi: 10.1071/EA9890918

Lawn RJ, Cottrell A (1988) Wild mungbean and its relatives in Australia. Biologist 35, 267-273.

Lawn RJ, Holland AE (2003) Variation in the Vigna lanceolata Benth. Complex for traits of taxonomic, adaptive or agronomic interest. Australian Journal of Botany 51, 295-308. doi: 10.1071/BT02105
Lawn RJ, Watkinson AR (2002) Habitat, morphological diversity, and distribution of the genus Vigna Savi in Australia. Australian Journal of Agricultural Research 53, 1305-1316. doi: 10.1071/AR02065

Menancio-Hautea DI, Kumar L, Danesh D, Young ND (1992) A genome map for mungbean [Vigna radiata $(\mathrm{L}$.) Wilczek] based on DNA genetic markers $(2 \mathrm{~N}=2 \mathrm{X}=22)$. In 'Genome maps'. (Ed. SJ O’Brien) pp. 6.259-6.261. (Cold Spring Harbor Laboratory Press: New York)

Rebetzke GJ (1994) Attributes of potential adaptive and agronomic significance in the wild mungbean (Vigna radiata (L.) Wilczek ssp. sublobata (Roxb) Verdc.). MAgrSc thesis, University of Queensland, Australia.

Roberts EH, Summerfield RJ (1987) Measurement and prediction of flowering in annual crops. In 'Manipulation of flowering'. (Ed. JG Atherton) pp. 17-50. (Butterworths: London)

Saravanakumar P, Kaga A, Tomooka N, Vaughan DA (2004) AFLP and RAPD analyses of intra- and interspecific variation in some Vigna subgenus Ceratotropis (Leguminosae) species. Australian Journal of Botany 52, 417-424. doi: 10.1071/BT03091

Smartt J (1978) The evolution of pulse crops. Economic Botany 32, $185-198$.

Tateishi Y (1984) Contributions to the genus Vigna (Leguminosae) in Taiwan I. Science Report Tohoku University 4th Series (Biology) 38, 335-350.

Tomooka N, Lairungreang C, Nakeeraks P, Egawa Y, Thavarasook C (1992) Development of bruchid-resistant mungbean line using wild mungbean germplasm. Plant Breeding 109, 60-66.

Verdcourt B (1970) Studies in the Leguminsae-Papilionoideae for the 'Flora of Tropical East Africa. IV'. Kew Bulletin 24, 504-555.

Verdcourt B (1979) A manual of New Guinea legumes. Botany Bulletin No. 11, Office of Forests, Lae, Papua New Guinea.

Manuscript received 14 June 2005, accepted 14 September 2005 